\title{
Genetic selection improvement of the strawberry assortment in the Central Black Earth Region conditions
}

\author{
Irina Luk'yanchuk*, Ekaterina Zhbanova, Ksenia Zaitseva, and Alexander Lyzhin \\ "I.V. Michurin Federal Scientific Center", 393774 Michurinsk, Russian Federation
}

\begin{abstract}
The assessment of the polymorphic genetic collection of the genus Fragaria L. according to the most important economic and biological traits was carried out and the intervals of their variation were determined. Based on field monitoring of the general condition of plants and testing samples for the presence of endophytic microbiota, highly adaptive genotypes were identified: Tsaritsa, Urozhaynaya CGL, Pamyati Zubova, Flora, Privlekatelnaya, Vima Tarda, Elianny, 927-80 (298-19-9-43 $\times$ Rubinovyy kulon), 34-12 (922-67 × Privlekatelnaya), etc. Valuable genotypes by yield (Flora, Tsaritsa, Elianny, 75-30 (Tokado $\times$ Elianny), 56-5 (922-67 × Privlekatelnaya), 35-5 (922-67 × Maryshka), etc.) and the fruit biochemical composition with high accumulation: sugars Olimpiyskaya nadezhda, 915-104 (298-22-19-21 × Feyerverk), 28-19 (Lakomaya $\times$ Maryshka), etc.; ascorbic acid - Kokinskaya zarya, Privlekatelnaya, Kupchikha, Tsaritsa, Marshall, 56-9, 56-12 (Gigantella Maxim $\times$ Privlekatelnaya), etc.; anthocyanins - Alona, Feyerverk, 35-16 (922-67 × Maryshka), 928-12 (298-19-9-43 × Privlekatelnaya), etc. were identified. The combination of functional alleles of the FaOMT and FaFAD1 genes of the fruit aroma complex was detected in varieties Kubata, Tsaritsa, Kimberly, Sonata, Tokado, etc.
\end{abstract}

\section{Introduction}

Strawberry is among the most widely cultivated berry crops in the world $[1,2]$.

The profitability of strawberry cultivation is due to the ratio of many factors, the most important of which is yield, which in turn depends on the conditions prevailing during the growth of plants. In the conditions of climate destabilization, fungal epiphytoties, and increased attention to the quality of the berry products, it is necessary to carry out targeted breeding work to create competitive strawberry varieties characterized by a complex of such characteristics as: resistance to unfavorable factors of growing conditions, high stable productivity and commodity consumer qualities of fruits. At the same time, the analysis and selection of promising genotypes should be based on a complex assessment of polymorphic forms using the potential of modern and original methods of molecular genetics, breeding, biochemistry and phytopathology [3-5].

\footnotetext{
${ }^{*}$ Corresponding author: irina.lk2011@yandex.ru
} 
In this regard, the purpose of our research was the screening of valuable strawberry genotypes based on the analysis of the genetic collection of the genus Fragaria L. according to a complex of the most important economic and biological traits.

\section{Materials and methods}

The studies were carried out in 2018-2020. Biological material was represented by wild species of genus Fragaria L., and strawberry varieties and promising hybrid forms.

Assessment of winter damage and general condition of plants, resistance to pathogens, yield, fruit taste was carried out according to "Program and methodology of variety studies for fruit, berry and nut crops" [6]. The assessment of the adaptive potential of strawberry plants based on the analysis of the biology and dynamics of the development of endophytic microbiota was carried out according to the methods described earlier [7]. The content of the components of the chemical composition of fruits (sugars, organic acids, vitamin $\mathrm{C}$, anthocyanins) was determined by standard methods [8]. The FaFAD1 and FaOMT genes of the aromatic complex of the fruits were identified by molecular genetic analysis using diagnostic DNA markers FaFAD1 [9] and FaOMT-SI/NO [10]. Statistical analysis of the obtained results was carried out using the package of mathematical statistics Microsoft Excel 2007.

\section{Results and discussion}

The winter hardiness is an important component of the adaptive potential of strawberry in the Central Black Earth Region of Russia. During the research period, the greatest damage to strawberry plants was noted after the relatively severe winter of $2018 / 2019$. During this period, the air temperature dropped to $-10.8^{\circ} \mathrm{C}$ in the second decade of November in the absence of snow and to $-15.6^{\circ} \mathrm{C}$ at the end of November with an insignificant snow level of $2 \mathrm{~cm}$. Unfavorable winter conditions made it possible to assess the winter hardiness of the strawberry original species, varieties, interspecific and intervarietal hybrids and to identify the most promising forms for this trait. The degree of winter damage to the studied strawberry genotypes ranged from 0 to 3 score. Most $(63.0 \%)$ of the analyzed strawberry collection were forms without signs of winter damage, which is due to the favorable conditions of the autumn-winter period of recent years and the prevalence of highly winter hardiness hybrids in the analyzed strawberry collection. The number of strawberry forms with winter damage up to 1 score was $26.8 \%$, with winter damage by 2 score $-3.7 \%$, with winter damage by 3 score $-6.5 \%$ (Figure 1 .).

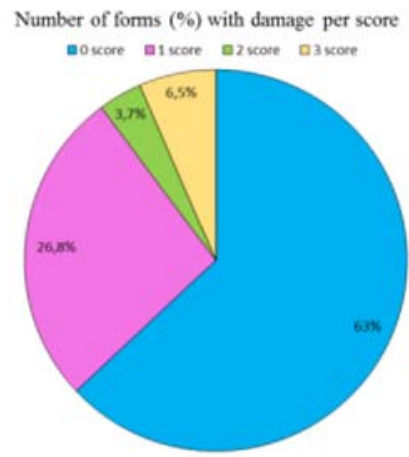

Fig. 1. Distribution of strawberry genotypes by the degree of winter damage 
The wild species $F$. ovalis, $F$. virginiana ssp. platypetala, F. moschata and F. orientalis, and strawberry varieties Bogema, Kokinskaya zarya, Privlekatelnaya, Troitskaya, Urozhaynaya CGL, Tsaritsa, Lastochka and Rusich, and interspecific (298-19-9-43 (FB $F$. orientalis, $F$. moschata, $F . \times$ ananassa $), 932-29$ ( $F$. virginiana ssp. platypetala $\times$ Feyerverk), 34-2, 34-12 (922-67 × Privlekatelnaya), 927-8, 927-14, 927-80 (298-19-9-43 × Rubinovyy kulon), 26-5, 26-8 (Rubinovyy kulon × 298-19-9-43), 915-104 (298-22-19-21 × Feyerverk), 35-8, 35-10 (922-67 ×Maryshka)) and intervarietal (56-17, 56-51 (Gigantella Maxim $\times$ Privlekatelnaya), 914-13, 914-27, 914-100 (Festivalnaya $\times$ Privlekatelnaya), 91116 (Feyerverk $\times$ Festivalnaya romashka), 30-5 (Feyerverk $\times$ Privlekatelnaya)) hybrid forms are characterized high winter hardiness (signs of winter damage are absent) in the Central Black Earth Region conditions (Table 1.).

Table 1. The degree of winter damage of wild species, varieties and hybrid forms of strawberry

\begin{tabular}{|c|c|c|c|}
\hline \multicolumn{4}{|c|}{ The degree of winter damage of plants, score } \\
\hline 0 & 1 & 2 & 3 \\
\hline $\begin{array}{l}\text { F. ovalis Rydb., } \\
\text { F. virginiana Duch. } \\
\text { ssp. platypetala, } \\
\text { F. moschata Duch., } \\
\text { F. orientalis Los., } \\
\text { 298-19-9-43, } \\
\text { Privlekatelnaya, } \\
\text { Urozhaynaya CGL, } \\
\text { Kokinskaya zarya, } \\
\text { Tsaritsa, } \\
\text { Lastochka, } \\
\text { Bogema, } \\
\text { Troitskaya, } \\
\text { Rusich, } \\
\text { 915-104, 911-16, } \\
\text { 914-100, 914-13, } \\
\text { 914-27, 927-14, 927-8, } \\
\text { 927-80, 932-29, 26-5, } \\
\text { 26-8, 34-2, 34-12, 35-8, } \\
\text { 35-10, 30-5, 56-17, } \\
\text { 56-51 }\end{array}$ & $\begin{array}{l}\text { Rubinovyy kulon, } \\
\text { Gigantella Maxim, } \\
\text { Lakomaya, } \\
\text { Yarkaya, } \\
\text { Feyerverk, } \\
\text { VimaTarda, } \\
\text { Festivalnaya (control), } \\
\text { Yuniol, } \\
\text { Krymchanka 87, } \\
\text { 922-67, 914-9, 914-44, } \\
\text { 914-59, 914-62, 913- } \\
\text { 102, } \\
\text { 26-10, 29-14, 35-5, 35-7, } \\
\text { 35-16, 25-2, 28-19, 31-2, } \\
\text { 56-7,56-19, 56-20 }\end{array}$ & $\begin{array}{l}\text { Girlyanda, } \\
\text { Prazdnichnaya, } \\
\text { Maryshka, } \\
\text { Rusanovka, } \\
\text { Kimberly, } \\
\text { 933-4, 914-67, } \\
928-12, \quad 29-4, \\
29-15, \quad 35-1, \\
19-6,25-1,30- \\
1,56-9, \\
21-14\end{array}$ & $\begin{array}{l}\text { Torpeda, } \\
\text { Vima } \\
\text { Zanta, } \\
\text { Barlidaun, } \\
\text { Symphony, } \\
\text { Sonata, } \\
914-30, \\
928-25,19- \\
4, \quad 28-18, \\
56-12\end{array}$ \\
\hline
\end{tabular}

Strawberry varieties Rubinovyy kulon, Gigantella Maxim, Lakomaya, Yarkaya, Feyerverk, Vima Tarda, Festivalnaya, Yuniol and Krymchanka 87, and interspecific (92267 ( $\mathrm{FB}_{3}$ F. ovalis), 913-102 (Urozhaynaya CGL $\times$ 298-19-9-43), 29-14 (Lakomaya $\times 298$ 19-9-43), 26-10 (Rubinovyy kulon $\times$ 298-19-9-43), 35-5, 35-7, 35-16 (922-67 × Maryshka)) and intervarietal (25-2 (Rubinovyy kulon $\times$ Maryshka), 31-2 (Feyerverk $\times$ Rusanovka), 914-9, 914-44, 914-59, 914-62 (Festivalnaya $\times$ Privlekatelnaya), 28-19 (Lakomaya $\times$ Maryshka), 56-7, 56-19, 56-20 (Gigantella Maxim $\times$ Privlekatelnaya)) hybrid forms are characterized insignificant degree of winter damage (up to 1 score).

The strawberry varieties and forms with winter damage of plants from 2 to 3 score are moderate winter hardiness, but in this group there are clear differences in the degree of damage by low temperatures. Strawberry varieties Girlyanda, Prazdnichnaya, Maryshka, Rusanovka and Kimberly, and interspecific (35-1 (922-67 × Maryshka), 928-12 (298-19-9$43 \times$ Privlekatelnaya), 933-4 (F. virginiana ssp. platypetala $\times$ Rubinovyy kulon), 29-4, 2915 (Lakomaya $\times 298-19-9-43)$ ) and intervarietal (914-67 (Festivalnaya $\times$ Privlekatelnaya), 19-6 (Prazdnichnaya $\times$ Rusanovka), 25-1 (Rubinovyy kulon $\times$ Maryshka), 21-14 (Urozhaynaya CGL $\times$ Rubinovyy kulon), 56-9 (Gigantella Maxim $\times$ Privlekatelnaya), 30-1 (Feyerverk $\times$ Privlekatelnaya)) hybrids are characterized winter damage to 2 score. These genotypes later recovered in growth and bore fruit normally. The strawberry varieties Torpeda, Vima Zanta, Barlidaun, Symphony and Sonata and hybrid forms 928-25 (298-19- 
9-43 $\times$ Privlekatelnaya), 914-30 (Festivalnaya $\times$ Privlekatelnaya), 19-4 (Prazdnichnaya $\times$ Rusanovka), 28-18 (Lakomaya $\times$ Maryshka), 56-12 (Gigantella Maxim $\times$ Privlekatelnaya) are characterized winter damage to 3 score. These genotypes were greatly weakened in growth, the leaves were small and fruits were absent.

The general condition of plants in the analyzed strawberry collection was estimated at 2-5 score, which is additionally confirmed by the method of bioindicators based on endophytic microbiota, which is systemically present in the plant. At strawberry forms characterized by a high degree of adaptation to stress factors (varieties Pamyati Zubova, Tsaritsa, Flora, Kokinskaya zarya, Urozhaynaya CGL, Yarkaya, Troitskaya, Privlekatelnaya, Vima Tarda and Elianny, and hybrid seedlings 298-19-9-43 (FB $F$. orientalis, F. moschata, $F$. $\times$ ananassa), 927-80 (298-19-9-43 $\times$ Rubinovyy kulon), 932-29 $(F$. virginiana ssp. platypetala $\times$ Feyerverk), 34-12 $(922-67 \times$ Privlekatelnaya) $)$, the indicators of bacterial microbiota had rather high values (from 67.7 to $80.5 \%$ ) with a low accumulation of fungal (4.5-5.9\%) and mixed (11.3-13.6\%) infection, and low percentage of negative tests $(0-16.5 \%)$. Strawberry varieties and forms, the general condition of which was assessed by 2-3 score (Symphony, Barlidaun, Sonata, 28-18 (Lakomaya $\times$ Maryshka), 19-4 (Prazdnichnaya $\times$ Rusanovka), 56-12 (Gigantella Maxim $\times$ Privlekatelnaya)), were characterized by a low frequency of bacterial testing (32.6-50.7\%), a large accumulation of fungal (10.2-15.8\%) and mixed (25.3-29.7\%) microbiota, and high values of negative tests $(32.7-42.2 \%)$.

The yield of the analyzed strawberry genotypes varied from $92.4 \mathrm{c} / \mathrm{ha}$ to $143.8 \mathrm{c} / \mathrm{ha}$. Strawberry genotypes Urozhaynaya CGL, Flora, Tsaritsa, Elianny, Aprica, Pamyati Zubova, 75-30 (Tokado $\times$ Elianny), 56-5 (922-67 $\times$ Privlekatelnaya) and 35-5 (922-67 $\times$ Maryshka) had a yield of more than $120.0 \mathrm{c} / \mathrm{ha}$.

The biochemical composition of the fruits is an important consumer attribute of strawberry genotypes. Sugars in fruits of the studied strawberry varieties and forms accumulated in the range 5.6-11.1\% with an average value of $9.0 \%$. The high level of sugar accumulation (10\% or more) in fruits was noted in strawberry genotypes Alena, Girlyanda, Izbrannitsa, Kokinskaya zarya, Olimpiyskaya nadezhda, Privlekatelnaya, Feyerverk, Flora, Tsaritsa, F. virginiana ssp.platypetala, 915-104 (298-22-19-21 × Feyerverk), 28-19 (Lakomaya $\times$ Maryshka), 30-5 (Feyerverk $\times$ Privlekatelnaya) and 932-29 (F. virginiana ssp. platypetala $\times$ Feyerverk). The content of titratable acids in the collection of the studied strawberry forms varied from $0.60 \%$ to $1.21 \%$, with an average value of $0.95 \%$. Strawberry varieties and forms Lastochka, Olimpiyskaya nadezhda, Tsaritsa, Vima Zanta, 35-7, 35-10 (922-67 × Maryshka), 25-2 (Rubinovyy kulon $\times$ Maryshka), 932-29 (F. virginiana ssp. platypetala $\times$ Feyerverk), 28-19 (Lakomaya $\times$ Maryshka), 30-1 (Feyerverk $\times$ Privlekatelnaya) were characterized by an optimal balance of sugars and organic acids, and dessert fruit taste (Table 2. and 3.).

Ascorbic acid in fruits of analyzed strawberry genotypes was contained in the range from 48.0 to $96.8 \mathrm{mg} / 100 \mathrm{~g}$ with an average value of $71.9 \mathrm{mg} / 100 \mathrm{~g}$ (Table 2.).

Table 2. Chemical composition of fruits of strawberry varieties and forms

\begin{tabular}{|l|l|l|l|l|}
\hline Genotype & Sugars, \% & $\begin{array}{l}\text { Titratable } \\
\text { acidity, \% }\end{array}$ & $\begin{array}{l}\text { Ascorbic } \\
\text { acid, mg/100 g }\end{array}$ & $\begin{array}{l}\text { Anthocyanin } \\
\text { s, } \\
\mathrm{mg} / 100 \mathrm{~g}\end{array}$ \\
\hline Alena & 10.7 & 0.67 & 51.9 & 124.5 \\
\hline Barlidaun & 9.2 & 1.13 & 52.8 & 37.3 \\
\hline Bogema & 7.6 & 1.02 & 64.2 & 24.8 \\
\hline Vima Tarda & 7.2 & 1.07 & 70.4 & 53.1 \\
\hline Vima Zanta & 9.7 & 0.75 & 60.7 & 51.9 \\
\hline Gigantella Maxim & 7.4 & 1.21 & 66.0 & 58.0 \\
\hline Girlyanda & 11.1 & 0.96 & 85.8 & 57.8 \\
\hline Divnaya & 9.4 & 0.86 & 81.8 & 21.8 \\
\hline
\end{tabular}




\begin{tabular}{|c|c|c|c|c|}
\hline Zenit & 9.1 & 0.96 & 67.8 & 72.3 \\
\hline Izbrannitsa & 11.1 & 0.80 & 79.2 & 47.1 \\
\hline Kokinskaya zarya & 10.4 & 0.64 & 96.8 & 69.6 \\
\hline Kupchikha & 6.3 & 0.60 & 88.9 & 68.9 \\
\hline Lastochka & 10.1 & 0.63 & 60.1 & 44.7 \\
\hline Marshall & 7.1 & 0.99 & 85.8 & 70.9 \\
\hline Neznakomka & 9.1 & 1.02 & 88.0 & 66.1 \\
\hline $\begin{array}{l}\text { Olimpiyskaya } \\
\text { nadezhda }\end{array}$ & 10.9 & 0.94 & 88.9 & 20.2 \\
\hline Pamyati Zubova & 7.9 & 1.04 & 75.3 & 66.7 \\
\hline Privlekatelnaya & 10.4 & 0.98 & 81.9 & 77.9 \\
\hline Red Gauntlet & 7.3 & 0.80 & 64.2 & 27.0 \\
\hline Troubadour & 5.6 & 0.84 & 58.1 & 36.1 \\
\hline Urozhaynaya CGL & 8.8 & 1.14 & 57.9 & 36.8 \\
\hline Feyerverk & 10.6 & 0.91 & 48.4 & 111.8 \\
\hline Festivalnaya & 9.1 & 1.10 & 96.8 & 31.3 \\
\hline $\begin{array}{l}\text { Festivalnaya } \\
\text { (apomikt) }\end{array}$ & 6.8 & 1.15 & 81.0 & 34.2 \\
\hline Flora & 10.8 & 1.19 & 68.9 & 62.5 \\
\hline Tsaritsa & 10.3 & 0.82 & 93.3 & 57.2 \\
\hline $\begin{array}{l}298-19-9-43 \quad\left(\mathrm{FB}_{2}\right. \\
F . \quad \text { orientalis, } \\
\text { F. moschata, F. } \times \\
\text { ananassa })\end{array}$ & 8.4 & 1.13 & 48.0 & 43.4 \\
\hline $\begin{array}{l}\text { F. virginiana } \mathrm{ssp} . \\
\text { platypetala }\end{array}$ & 10.6 & 1.21 & 51.0 & 39.2 \\
\hline $\operatorname{Mean}(x)$ & 9.0 & 0.95 & 71.9 & 54.0 \\
\hline $\begin{array}{ll}\text { Standard } & \text { errors } \\
\left(\boldsymbol{S}_{(x)}\right) & \\
\end{array}$ & 0.31 & 0.04 & 2.91 & 4.66 \\
\hline Min & 5.6 & 0.60 & 48.0 & 20.2 \\
\hline Max & 11.1 & 1.21 & $\begin{array}{l}96.8 \\
\end{array}$ & 124.5 \\
\hline $\begin{array}{l}\text { Coefficient } \\
\text { variation }(V), \%\end{array}$ & 17.9 & 19.4 & 21.4 & 45.6 \\
\hline
\end{tabular}

The high level of ascorbic acid accumulation $(80.0 \mathrm{mg} / 100 \mathrm{~g}$ or more) in fruits was noted in strawberry varieties Festivalnaya, Kokinskaya zarya, Tsaritsa, Neznakomka, Girlyanda, Divnaya, Festivalnaya (apomikt), Privlekatelnaya, Kupchikha, Olimpiyskaya nadezhda and Marshall. The content of anthocyanins in fruits of analyzed strawberry varieties varied from $20.2 \mathrm{mg} / 100 \mathrm{~g}$ (Olimpiyskaya nadezhda) to $124.5 \mathrm{mg} / 100 \mathrm{~g}$ (Alena) with an average value of $54.0 \mathrm{mg} / 100 \mathrm{~g}$ (Table 2.). The high level of anthocyanins accumulation (100.0 mg/100 $\mathrm{g}$ or more) in fruits was noted in strawberry varieties Feyerverk and Alena. The varieties Kupchikha, Privlekatelnaya and Pamyati Zubova were also characterized by a dark color of fruits and an increased accumulation of anthocyanins.

The ascorbic acid in fruits of the studied strawberry hybrid seedlings accumulated in the range 53.1-108.9 mg/100 g, anthocyanins were 19.2-122.6 mg/100 g (Table 3.).

Table 3. Chemical composition of fruits of strawberry selected forms

\begin{tabular}{|l|l|l|l|l|l|}
\hline Genotype & \multicolumn{1}{|c|}{$\begin{array}{c}\text { Origin } \\
+\times \hat{\gamma}\end{array}$} & Sugars, \% & $\begin{array}{l}\text { Titratable } \\
\text { acidity, } \%\end{array}$ & $\begin{array}{l}\text { Ascorbic } \\
\text { acid, mg/100 } \\
\mathrm{g}\end{array}$ & $\begin{array}{l}\text { Anthocyani } \\
\mathrm{ns}, \\
\mathrm{mg} / 100 \mathrm{~g}\end{array}$ \\
\hline $915-104$ & $298-22-19-21 \times$ Feyerverk & 10.0 & 1.05 & 84.1 & 46.3 \\
\hline $932-29$ & $\begin{array}{l}\text { F. virginiana ssp. platypetala } \\
\times \text { Feyerverk }\end{array}$ & 11.3 & 0.94 & 57.2 & 36.2 \\
\hline $34-12$ & $922-67 \times$ Privlekatelnaya & 9.6 & 0.94 & 56.1 & 59.3 \\
\hline $928-12$ & $\begin{array}{l}298-19-9-43 \times \\
\text { Privlekatelnaya }\end{array}$ & 9.0 & 0.89 & 64.0 & 121.4 \\
\hline $30-1$ & Feyerverk $\times$ Privlekatelnaya & 8.4 & 0.72 & 64.0 & 98.7 \\
\hline $20-8$ & Prazdnichnaya $\times$ Dedanka & 10.7 & 0.75 & 83.4 & 19.2 \\
\hline $913-102$ & Urozhaynaya CGL $\times 298-19-$ & 9.9 & 1.10 & 74.8 & 33.1 \\
\hline
\end{tabular}




\begin{tabular}{|c|c|c|c|c|c|}
\hline & $9-43$ & & & & \\
\hline $21-14$ & $\begin{array}{l}\text { Urozhaynaya CGL } \times \\
\text { Rubinovyy kulon }\end{array}$ & 7.9 & 0.78 & 57.7 & 122.6 \\
\hline $25-1$ & \multirow{2}{*}{ Rubinovyy kulon $\times$ Maryshka } & 7.2 & 0.85 & 79.0 & 103.4 \\
\hline $25-2$ & & 8.0 & 0.73 & 60.3 & 60.6 \\
\hline $922-70$ & $\begin{array}{l}(516-167 \times \text { Cardinal }) \times \\
\text { Privlekatelnaya }\end{array}$ & 8.7 & 1.0 & 73.5 & 45.8 \\
\hline $28-18$ & \multirow{2}{*}{ Lakomaya $\times$ Maryshka } & 8.4 & 0.81 & 67.8 & 20.9 \\
\hline $28-19$ & & 11.7 & 0.85 & 83.8 & 41.7 \\
\hline $921-32$ & $\begin{array}{l}(516-167 \times \text { Cardinal }) \times \\
\text { Feyerverk }\end{array}$ & 10.0 & 0.95 & 65.8 & 77.6 \\
\hline $26-5$ & \multirow{3}{*}{$\begin{array}{l}\text { Rubinovyy kulon } \times 298-19-9 \text { - } \\
43\end{array}$} & 9.1 & 0.86 & 61.2 & 54.3 \\
\hline $26-8$ & & 7.5 & 0.95 & 53.1 & 35.2 \\
\hline $26-10$ & & 9.7 & 0.91 & 66.7 & 58.5 \\
\hline $914-13$ & \multirow{2}{*}{$\begin{array}{l}\text { Festivalnaya } \times \\
\text { Privlekatelnaya }\end{array}$} & 8.0 & 0.90 & 60.1 & 66.4 \\
\hline $914-27$ & & 9.4 & 0.88 & 90.2 & 81.6 \\
\hline $35-7$ & \multirow{4}{*}{ 922-67 × Maryshka } & 9.7 & 0.86 & 76.8 & 46.6 \\
\hline $35-8$ & & 8.6 & 1.0 & 66.0 & 72.1 \\
\hline $35-10$ & & 9.6 & 0.86 & 66.5 & 81.6 \\
\hline $35-16$ & & 9.6 & 0.91 & 62.3 & 113.8 \\
\hline $933-4$ & $\begin{array}{l}\text { F. virginiana } \text { ssp. platypetala } \\
\times \text { Rubinovyy kulon }\end{array}$ & 8.7 & 0.92 & 63.4 & 46.7 \\
\hline $56-7$ & \multirow{7}{*}{$\begin{array}{l}\text { Gigantella Maxim } \times \\
\text { Privlekatelnaya }\end{array}$} & 7.9 & 1.18 & 97.2 & 51.8 \\
\hline $56-8$ & & 8.0 & 1.01 & 92.0 & 44.2 \\
\hline $56-9$ & & 8.8 & 0.98 & 108.9 & 43.8 \\
\hline $56-12$ & & 8.6 & 1.02 & 100.6 & 62.5 \\
\hline $56-17$ & & 7.2 & 1.22 & 83.2 & 61.9 \\
\hline $56-19$ & & 8.0 & 0.81 & 68.2 & 62.6 \\
\hline $56-20$ & & 9.2 & 0.99 & 76.8 & 69.8 \\
\hline \multicolumn{2}{|c|}{$\operatorname{Mean}(x)$} & 9.0 & 0.92 & 73.0 & 62.6 \\
\hline \multicolumn{2}{|c|}{ Standard errors $\left(S_{(x)}\right)$} & 0.20 & 0.02 & 2.55 & 4.87 \\
\hline \multicolumn{2}{|l|}{ Min } & 7.2 & 0.72 & 53.1 & 19.2 \\
\hline \multicolumn{2}{|l|}{$\operatorname{Max}$} & 11.7 & 1.22 & 108.9 & 122.6 \\
\hline \multicolumn{2}{|c|}{ Coefficient of variation $(\mathrm{V}), \%$} & 12.4 & 12.8 & 19.4 & 43.4 \\
\hline
\end{tabular}

The high level of ascorbic acid accumulation $(100.0 \mathrm{mg} / 100 \mathrm{~g}$ or more) in fruits was noted in strawberry selected forms 56-9, 56-12 (Gigantella Maxim $\times$ Privlekatelnaya). The high level of anthocyanins accumulation $(100.0 \mathrm{mg} / 100 \mathrm{~g}$ or more) in fruits was noted in strawberry hybrids 21-14 (Urozhaynaya CGL $\times$ Rubinovyy kulon), 35-16 (922-67 × Maryshka), 928-12 (298-19-9-43 $\times$ Privlekatelnaya) and 25-1 (Rubinovyy kulon $\times$ Maryshka).

An important consumer trait of strawberry fruits is their aroma. The strawberry fruit aroma is due to the content of a large amount of flavor volatile aromatic organic compounds. Most important components to strawberry fruit aroma are about 20 compounds, which include $\gamma$-decalactone (fruity, sweet or peachy aroma) and mesifurane (fruity and caramel aroma) $[9,11]$. The $\gamma$-decalactone content in strawberry fruits is determined by the expression of the FaFAD1 gene [9], mesifurane - by the FaOMT gene [10].

In the analyzed collection of strawberry varieties the FaOMT gene was identified in $87.8 \%$ forms, the FaFAD1 gene was identified in $26.8 \%$ forms. Examples of the obtained electrophoresis profiles of the used diagnostic DNA markers are shown in Figure 2. and Figure 3. 


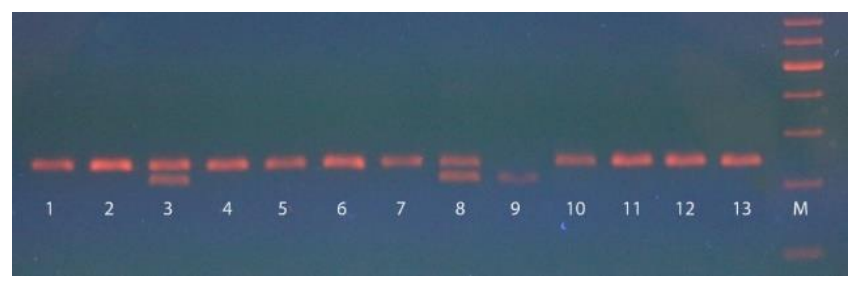

Fig. 2. Electrophoresis profile of marker FaOMT-SI/NO at strawberry genotypes: 1 - Borovitskaya, 2 - 298-19-9-43, 3 - 26-5, 4 - Korona, 5 - Kimberly, 6 - Yarkaya, 7 - Troitskaya, 8 - Ostara, 9 Quicky, 10 - Polka, 11 - 932-29, 12 - Kubata, 13 - Tsaritsa, M - Molecular weight marker

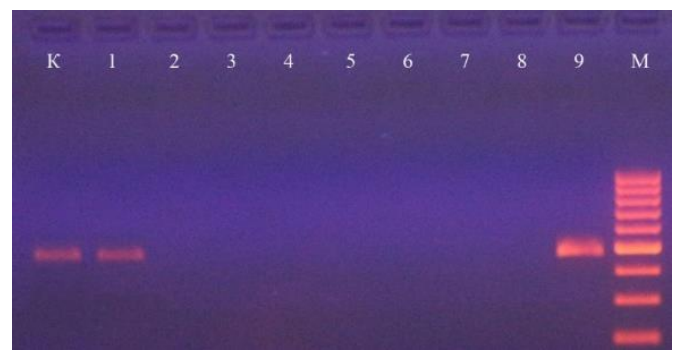

Fig. 3. Electrophoresis profile of marker FaFAD1-F/R at strawberry genotypes: $\mathrm{K}-$ control (F. orientalis Los.), 1 - Kubata, 2 - 56-5, 3 - 26-5, 4 - Korona, 5 - Troitskaya, 6 - Yarkaya, 7 - 932-29, 8 - Ostara, 9 - Tsaritsa, M - Molecular weight marker

In our earlier studies [12], the FaOMT gene was detected in $86.1 \%$ analyzed forms, the FaFAD1 gene - in $25.6 \%$ analyzed forms, which is consistent with the presented results. Among the analyzed Russian strawberry varieties, the number of forms with the FaOMT and FaFAD1 genes was $84.0 \%$ and $16.0 \%$ respectively. Among the analyzed foreign strawberry varieties, the studied genes were identified in $93.7 \%$ and $43.7 \%$ genotypes. The combination of the FaOMT and FaFADl genes was detected in the varieties Kubata, Tsaritsa (Russian breeding), Kimberly, Marshall, Sonata, Tokado, Red Gauntlet, Vima Tarda (foreign breeding), which allows us to recommend them as promising sources in strawberry breeding for fruit aroma.

\section{Conclusion}

Thus, in the Central Black Earth Region conditions, the studied of strawberry varieties and hybrid seedlings, and wild species of the genus Fragaria according to the winter hardiness, the plant general condition, yield, biochemical composition (content of sugars, organic acids, ascorbic acid, and anthocyanins), taste and genetic determinants of fruit aroma. The intervals of variation of the indicated traits were determined. For each of the traits, promising forms was identified.

\section{References}

1. F. Giampieri, S. Tulipani, J.M. Alvarez-Suarez, J.L. Quiles, B. Mezzetti, M. Battino, Nutrition, 28(1), 9 (2012)

2. K. Hummer, J.F. Hancock, Genetics and Genomics of Rosaceae, 7, 413 (2009)

3. B. Mezzetti, F. Giampieri, Y.T. Zhang, C.F. Zhong, Journal of Berry Research, 8(3), 205 (2018) 
4. I.V. Luk'yanchuk, E.V. Zhbanova, A.S. Lyzhin, Pomiculture and small fruits culture in Russia, 62, 48 (2020)

5. A.S. Lyzhin, I.V. Luk'yanchuk, Proceedings of the national academy of sciences of Belarus. Agrarian series, 58(3), 311 (2020)

6. E.N. Sedov, T.P. Ogoltsova, Program and methodology of variety studies for fruit, berry and nut crops, 608 (1999)

7. A.I. Ermakov, V.V. Arasimovich, N.P. Yarosh, Yu.V. Peruvian, G.A. Lukovnikov, M.I. Ikonnikova, Methods of biochemical research of plants, 430 (1987)

8. M.V. Maslova, I.V. Luk'yanchuk, K.V. Zaitseva, Pomiculture, 26, 345 (2014)

9. A.H. Chambers, J. Pillet, A. Plotto, J. Bai, V.M. Whitaker, K.M. Folta, BMC genomics, 15(1), 217 (2014)

10. Y. Zorrilla-Fontanesi, J.L. Rambla, A. Cabeza, J.J. Medina, J.F. Sánchez-Sevilla, V. Valpuesta, M.A. Botella, A. Granell, I. Amaya, Plant physiol., 159(2), 851 (2012)

11. M. Urrutia, J.L. Rambla, K.G. Alexiou, A. Granell, A. Monfort, Plant Physiol. Bioch., 121, 99 (2017)

12. A.S. Lyzhin, I.V. Luk'yanchuk, E.V. Zhbanova, Vavilov Journal of Genetics and Breeding, 24(1), 5 (2020) 